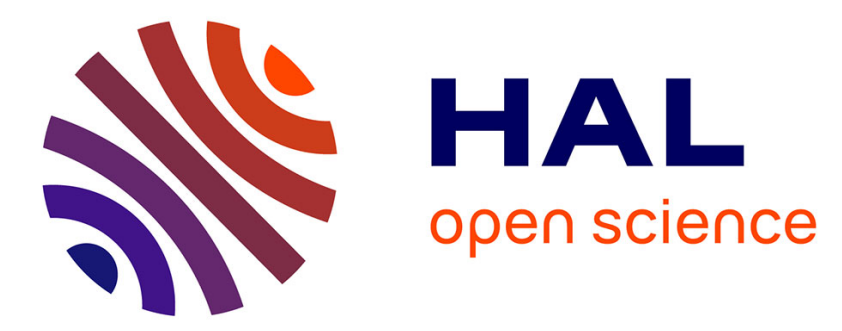

\title{
ENTREPRENEURIAL INTEREST, VISION AND THE SELF-EMPLOYMENT CHOICE DECISION IN UK REGIONS
}

\author{
Brian Ashcroft, Darryl Holden, Kenneth Low
}

\section{- To cite this version:}

Brian Ashcroft, Darryl Holden, Kenneth Low. ENTREPRENEURIAL INTEREST, VISION AND THE SELF-EMPLOYMENT CHOICE DECISION IN UK REGIONS. Regional Studies, 2009, 43 (08), pp.1075-1090. 10.1080/00343400802070878 . hal-00516208

\author{
HAL Id: hal-00516208 \\ https://hal.science/hal-00516208
}

Submitted on 9 Sep 2010

HAL is a multi-disciplinary open access archive for the deposit and dissemination of scientific research documents, whether they are published or not. The documents may come from teaching and research institutions in France or abroad, or from public or private research centers.
L'archive ouverte pluridisciplinaire HAL, est destinée au dépôt et à la diffusion de documents scientifiques de niveau recherche, publiés ou non, émanant des établissements d'enseignement et de recherche français ou étrangers, des laboratoires publics ou privés. 


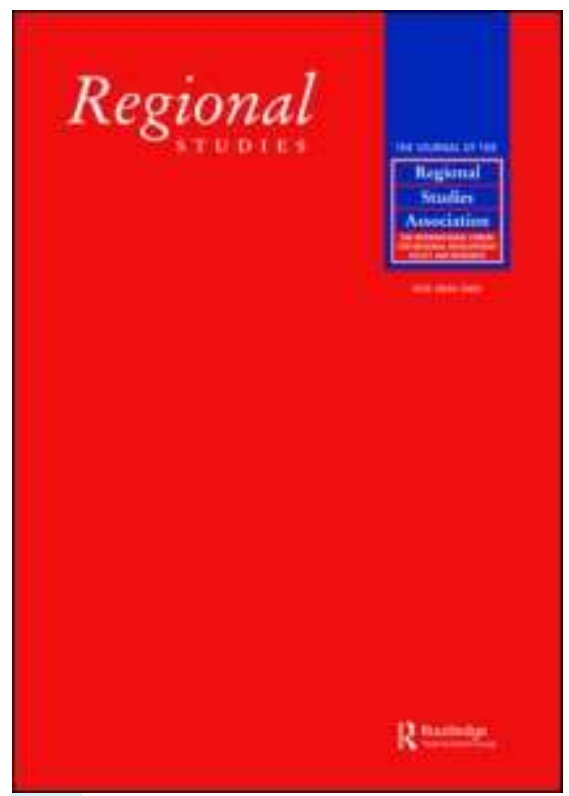

\section{ENTREPRENEURIAL INTEREST, VISION AND THE SELF- EMPLOYMENT CHOICE DECISION IN UK REGIONS}

\begin{tabular}{|r|l|}
\hline Journal: & Regional Studies \\
\hline Manuscript ID: & CRES-2006-0191.R2 \\
\hline Manuscript Type: & Main Section \\
\hline JEL codes: & $\begin{array}{l}\text { J23 - Employment Determination; Job Creation; Labor Demand; } \\
\text { Self-Employment < J2 - Time Allocation, Work Behavior, and } \\
\text { Employment Determination/Creation < J - Labor and Demographic } \\
\text { Economics, M13 - Entrepreneurship < M1 - Business Administration } \\
\text { Accounting, R11 - Regional Economic Activity: Growth, } \\
\text { Development, and Changes < R1 - General Regional Economics < R } \\
\text { - Urban, Rural, and Regional Economics, R15 - Econometric and } \\
\text { Input-Output Models|Other Models < R1 - General Regional } \\
\text { Economics < R - Urban, Rural, and Regional Economics }\end{array}$ \\
\hline Keywords: & \begin{tabular}{l} 
self-employment, entrepreneurship, firm formation, regional policy \\
\hline
\end{tabular} \\
\hline
\end{tabular}

\section{SCHOLARONE" Manuscripts}




\title{
ENTREPRENEURIAL INTEREST, VISION AND THE
}

\section{SELF-EMPLOYMENT CHOICE DECISION IN UK}

\section{REGIONS*}

\author{
Brian Ashcroft ${ }^{*}$, Darryl Holden ${ }^{+}$and Kenneth Low^ \\ Fraser of Allander Institute ${ }^{*} \wedge$ and Department of Economics ${ }^{*+} \wedge$, University of \\ Strathclyde and Centre for Public Policy for Regions ${ }^{*}$ (CPPR)
}

\begin{abstract}
First received: August 2006

Accepted: December 2007

In this paper we take the standard model of self-employment choice and extend it to allow for differences in the potential for self-employment amongst employees. Four groups of entrepreneurs are hypothesised: actual, potential, latent, and non-entrepreneurs. Both the standard model and the 'sequential' model are estimated on a UK dataset, allowing for both 'super' and standard region variations. The sequential model offers distinct advantages over the standard model. The results have implications for national and regional entrepreneurship policy because they reveal a clear distinction between the factors governing interest in entrepreneurship and those influencing start-up from within the interested group.
\end{abstract}

JEL Classification: J23, M13, R11, R15

Keywords: self-employment, entrepreneurship, firm formation, regional policy

L'esprit d'entreprise, la vision et le choix du travail indépendant dans les régions du R-U.

Ashcroft et al.

Le point de départ de cet article est le modèle type du choix du travail indépendant, et on le développe afin de tenir compte des différences quant aux qualités nécessaires pour que les salariés puissent travailler à leur propre compte. On émet une hypothèse relative à quatre groupes d'entrepreneurs: des entrepreneurs réels, potentiels, latents et autres. Le modèle type et le modèle 'séquentiel', tous les deux, sont estimés à partir d'un ensemble de données pour le R-U, qui tient compte des variations dans les régions 'super' et les régions type. Le modèle séquentiel offre des avantages particuliers par rapport au modèle type. Les résultats soulèvent des implications pour les politiques nationale et régionale en faveur de l'esprit d'entreprise parce qu'ils laissent voir une distinction très nette entre les facteurs qui influent sur l'intérêt pour l'esprit d'entreprise et ceux qui influent sur la création d'entreprise au sein du groupe intéressé. 
Travail indépendant / Esprit d'entreprise / Création d'entreprise / Politique régionale

Classement JEL: J23; M13; R11; R15

\author{
Interesse am Unternehmertum, unternehmerische Vision und die Entscheidung \\ zur Selbstständigkeit in den Regionen Großbritanniens \\ Brian Ashcroft, Darryl Holden and Kenneth Low
}

\begin{abstract}
In diesem Beitrag erweitern wir das Standardmodell der Entscheidung zur Selbstständigkeit, um die Unterschiede hinsichtlich der Potenziale von verschiedenen Angestellten zur Selbstständigkeit zu berücksichtigen. Es werden vier Gruppen von Unternehmern hypothetisiert: tatsächliche, potenzielle, latente und Nichtunternehmer. Anhand eines Datensatzes aus Großbritannien werden sowohl das Standard- als auch das 'sequenzielle' Modell geschätzt, wobei die Abweichungen von 'Super'- und Standardregionen berücksichtigt werden. Das sequenzielle Modell bietet gegenüber dem Standardmodell klare Vorteile. Die Ergebnisse wirken sich auf die nationalen und regionalen Grundsätze zur Unternehmensförderung aus, denn sie zeigen einen klaren Unterschied zwischen den Faktoren, die sich auf das Interesse am Unternehmertum auswirken, und den Faktoren, die innerhalb der interessierten Gruppe eine Unternehmensgründung beeinflussen.
\end{abstract} JEL Classification: J23, M13, R11, R15

Keywords:

Selbstständigkeit

Unternehmertum

Firmengründung

Regionalpolitik

Interés empresarial, visión y la opción del empleo autónomo en las regiones británicas Brian Ashcroft, Darryl Holden and Kenneth Low

\title{
Abstract
}

En este artículo tomamos el modelo estándar de la opción de empleo autónomo y lo ampliamos para tener en cuenta las diferencias en el potencial de trabajar por cuenta propia que tienen los empleados. Se muestran cuatro grupos de empresarios como hipótesis: empresarios actuales, potenciales, latentes y no empresarios. Se calculan tanto el modelo estándar como el modelo 'secuencial' en un conjunto de datos británicos, teniendo en cuenta las variaciones regionales 'super' y estándar. El modelo secuencial ofrece distintas ventajas en comparación con el modelo estándar. Los resultados afectan a la política empresarial tanto nacional como regional porque ponen de relieve una clara distinción entre los factores que gobiernan el interés empresarial y los que influyen en la creación de empresas dentro del grupo interesado.

Keywords:

Empleo autónomo

Interés empresarial

Creación de empresas

Política regional

JEL Classification: J23, M13, R11, R15

\footnotetext{
* The research in this paper was funded by the Economic and Social Research Council (ESRC Grant
}

Number: R000221752). We also acknowledge the support of Scottish Enterprise. We are especially 
grateful for the detailed comments of one anonymous referee and acknowledge the comments of another anonymous referee. All errors and omissions are the responsibility of the authors alone.

Postal Address: Fraser of Allander Institute

Department of Economics

Sir William Duncan Building

130 Rottenrow

Glasgow G4 0GE

Emails: b.k.ashcroft@strath.ac.uk d.holden@strath.ac.uk k.low@strath.ac.uk

\section{INTRODUCTION}

The promotion of entrepreneurship has become an important priority of national and regional policy amongst governments across the world. In the UK, for example, policies such as the Enterprise Allowance Scheme, the Business Expansion Scheme, and the Loan Guarantee Scheme were introduced at the national level. Furthermore, evidence of low entrepreneurial potential and firm formation in several UK peripheral regions (e.g. Storey and Johnson, 1987; Ashcroft, Love and Malloy, 1991), led to some regional specific policy initiatives, such as those in Scotland (Scottish Enterprise, 1992) and Wales (National Assembly for Wales, 2002).

The growing policy interest in small business and entrepreneurship underlines the importance of academic research into the determinants of entrepreneurship. We consider that of several lines of research the work on self-employment choice using cross-sectional data - for recent surveys see Le, 1999 and Parker 2004 - is of particular significance. These studies seek to apply some of the insights in models of entrepreneurial choice developed by Lucas (1978) and Kihlstrom and Laffont (1979), 
which in turn built on seminal work on the economic theory of entrepreneurship by Knight (1921) and Schumpeter (1950).

In this paper, we seek to address several research questions. First, we specify and test the standard model of self-employment/paid-employment choice, as developed by Rees and Shah (1986), Dolton and Makepeace (1990) and others, using a data set $^{\mathrm{i}}$ for the UK that allows regional differentiation. Secondly, we hypothesise that self-employment may be determined not only by objective capacity (entrepreneurial vision) but also by self-perceptions of that capacity and by individual preferences and attitudes towards self-employment and paid work. Psychological models of entrepreneurial potential consider that attitudes and perceptions may be more important than objective personal characteristics (Kreuger and Brazeal, 1994). The survey data used allows several attitudinal and preference variables to be constructed and brought into the estimation as well as objective human capital and location variables. Thirdly, we suggest and test an alternative approach, which allows for the hypothesised non-homogeneity of the employed workforce, in terms of their actual and desired status as entrepreneurs, with respect to the self-employment choice decision. Specifically, we recognise four relevant groups: actual entrepreneurs, potential entrepreneurs, latent entrepreneurs, and non-entrepreneurs. We consider the relative merits of sequential probit and ordered probit approaches to estimation and conclude that a sequential approach is to be preferred on a priori grounds.

The paper is in five parts. First, the standard model of entrepreneurial choice is outlined. Secondly, the sequential model is specified and the sequential and ordered probit approaches are discussed. Thirdly, we discuss the data set and the variables to 
be used in the estimation. In the fourth part, the results of the estimation of the standard and sequential models are presented and discussed ${ }^{\mathrm{ii}}$. The paper concludes with a summary of the findings and considers some implications for business birth rate policy, particularly at the regional level.

\section{THE STANDARD MODEL}

The standard model that has been applied to cross-section data is the probabilistic, or endogenous switching, model applied by, amongst others, Rees and Shah (1986), Gill (1988), Dolton and Makepeace (1990), de Wit (1993), and Clark and Drinkwater (2000) to the question of self-employment/paid employment selection.

The model reads:

$$
\begin{array}{ll}
E^{*} & =\delta_{1}\left(\ln \left(y_{s e}\right)-\ln \left(y_{p e}\right)\right)+\delta_{2} A+\varepsilon \\
\ln \left(y_{s e}\right)= & \theta_{s} Y+\varepsilon_{s} \\
& \\
\ln \left(y_{p e}\right)= & \theta_{p} Y+\varepsilon_{p}
\end{array}
$$

Individuals choose the employment status that offers them the highest expected utility. Given that $\delta_{1}$ is positive, individual i chooses self-employment if and only if $E^{*}$ is positive, otherwise wage-employment is chosen. Equation (1) indicates that the 
choice is assumed to depend on the difference between the logarithms of the potential income in the two alternatives $\left(\ln \left(y_{s e}\right)-\ln \left(\mathrm{y}_{\mathrm{pe}}\right)\right)$, a vector of observable characteristics of the individual $(A)$, and a disturbance term $(\varepsilon)$. Equations (2) and (3) are potential earnings equations where equation (2) gives actual earnings if the individual opts for self-employment and equation (3) gives actual earnings if the individual opts for paid employment. $Y$ is a vector of individual characteristics, and $\varepsilon_{s}$ and $\varepsilon_{p}$ are disturbance terms.

Equations (1), (2) and (3) constitute the structural form of the standard model ${ }^{\mathrm{iii}}$. Substitution of the income equations (2) and (3) into (1) produces a reduced form equation that is given by:

$$
E^{*} \quad=\quad \delta_{1}\left(\theta_{\mathrm{s}}-\theta_{\mathrm{p}}\right) Y+\delta_{2} A+\left(\varepsilon+\delta_{1}\left(\varepsilon_{s}-\varepsilon_{p}\right)\right)
$$

which is typically estimated as a probit.

\section{A SEQUENTIAL MODEL}

It is clear that in the literature on the employment status decision, the vectors of observable characteristics of the individual ( $A$ and $Y$ in equation (4)) are not simply ad hoc specifications. Characteristics are chosen to proxy in the estimation: the degree of risk aversion of the individual, work attributes, human capital and the degree of liquidity constraint. The underlying view of the entrepreneur is essentially that of Knight (1921). Knight viewed the entrepreneur as more willing to bear uninsurable 
risk, receiving profits as a reward for discharging this function, while being subject to a liquidity constraint because of the failure of capital markets to supply sufficient funds due to moral hazard and adverse selection problems. Knight's view of entrepreneurship contrasts with that of Schumpeter (1950) who argued that the functions of the capitalist and entrepreneur were quite separate, a view that was shared by other Austrian theorists of entrepreneurship, notably Kirzner (1979). However, the evidence of Evans and Leighton (1989), and Evans and Jovanovic (1989), who found that liquidity constraints did appear to bind so that the would-be entrepreneur must bear most of the risk inherent in his/her venture, supports Knight rather than the Austrians.

Blanchflower and Oswald (1998), on the other hand, argue that the theory underlying the empirical literature on entrepreneurial choice breaks with the main tenets of the classical theories of entrepreneurship. They suggest that the classical writings stressed three key aspects of entrepreneurship. First, that most individuals are not sufficiently alert or innovative to perceive business opportunities. Secondly, that an innovative entrepreneur may receive higher expected utility than he or she would as a regular worker, and thirdly, that attitude to risk is not the central characteristic which determines who becomes an entrepreneur. On this view, given the assumed higher utility from entrepreneurship and the relative unimportance of risk, the probability of running a business reduces to a function of the joint probability of having entrepreneurial vision and of having, or obtaining, capital. Blanchflower and Oswald test this model assuming that the probabilities depend upon a set of personal characteristics, and a set of regional and industrial characteristics. 
We do not go as far as Blanchflower and Oswald and accept a priori the view that entrepreneurship necessarily provides greater utility than paid employment, even though survey evidence suggests that the self-employed are more likely to be satisfied with their job than those in paid employment (Blanchflower, Oswald and Stutzer, 2001). There is considerable evidence that some who choose employee status may have a comparative advantage at it (Rees and Shah, 1986) or, at the very least, differ from self-employed individuals (Dolton and Makepeace, 1990). Moreover, the evidence that marginal, dispossessed, and previously low-wage workers are often forced to seek self-employment due to non-clearing labour markets would also appear to contradict Blanchflower and Oswald's assumption (Blau, 1985; Evans and Leighton, 1989). However, Blanchflower and Oswald's reminder that theorists such as Kirzner (1973) view the sine qua non of entrepreneurship as the perception of business opportunities is important, since it implies that not all individuals have entrepreneurial vision and that it may be incorrect to assume that the possibility of self-employment is open to all employees. Indeed, we can go further than Blanchflower and Oswald and argue that the set of potential entrepreneurs may be determined not only by objective capacity (entrepreneurial vision) but also by selfperceptions of that capacity and by individual preferences and attitudes towards selfemployment and paid work. Moreover, in view of the possibility of binding liquidity constraints, so that the potential entrepreneurs may have to bear most of the risk, then attitudes towards risk cannot be removed from the entrepreneurial choice decision. Psychological models ${ }^{\mathrm{iv}}$ of entrepreneurial potential consider that attitudes and perceptions may be more important than objective personal characteristics (Kreuger and Brazeal, 1994). And Evans and Leighton (1989) have suggested that economists 
might usefully incorporate in their models the many insights that are offered by the literature on entrepreneurship in sociology and psychology (p.532).

Moreover, in view of the hypothesised importance of entrepreneurial interest and entrepreneurial vision, we suggest that the self-employment choice decision can usefully be viewed, for analytical purposes, as a sequential process. Individuals first become interested in founding a firm; some then develop a vision, or find an idea, which they believe will be successful; and from this group a further subset go on to found a firm, presumably after having experienced a displacement event, and/or after overcoming capital and other constraints ${ }^{\mathrm{v}}$. We therefore define the following cases:

$E=1$ if the individual is not interested in founding a firm.

$E=2$ if the individual is interested but does not believe they have an appropriate idea.

$E=3$ if the individual is both interested and has an idea but has not set up a firm.

$E=4$ if the individual has set up a firm.

For any given sample, individuals in the labour force can therefore be assigned to one of four defined groups: the not interested group; the latent entrepreneurs, that is, those who are interested but do not believe that they have the appropriate vision and business idea; the potential entrepreneurs, that is, those who are interested and have a business idea but who have not yet started a firm; and actual entrepreneurs or the self employed. Given the assumptions that underlie the sequential probit (see 
Amemiya (1975) and Maddala (1983)), we can write the probabilities of an individual being in one of the four groups as:

$$
\begin{aligned}
& P_{1}=\Phi\left(b_{1} X\right)=P(\text { not interested }) \\
& P_{2}=\left[1-\Phi\left(b_{1} X\right)\right] \Phi\left(b_{2} X\right)=P(\text { latent }) \\
& P_{3}=\left[1-\Phi\left(b_{1} X\right)\right]\left[1-\Phi\left(b_{2} X\right)\right] \Phi\left(b_{3} X\right)=P(\text { potential }) \\
& P_{4}=\left[1-\Phi\left(b_{1} X\right)\right]\left[1-\Phi\left(b_{2} X\right)\right]\left[1-\Phi\left(b_{3} X\right)\right]=P(\text { self employed })
\end{aligned}
$$

where $\Phi$ is the cumulative distribution function of the standard normal.

Some discussion regarding the parameters $b_{2}$ and $b_{3}$ might be useful. The conditional probability:

$$
P(\text { latent/latent or potential or actual })=\Phi\left(b_{2} X\right)
$$

implies that the direction of the relationship between a variable included in $X$ and the probability of an individual being latent if that individual is latent, potential, or actual can be deduced from an examination of $b_{2}$. The same is not true for the unconditional probability $P$ (latent) since both $b_{1}$ and $b_{2}$ are involved. Note that the direction of the relationship between a variable and the unconditional $P$ (latent) can only be determined when the implied elements of $b_{1}$ and $b_{2}$ are of opposite signs ${ }^{\mathrm{vi}}$. Similar comments can be made regarding $b_{3}$ given

$$
P(\text { potential } / \text { potential or actual })=\Phi\left(b_{3} X\right)
$$


If desired, the probabilities that define the sequential model in (5), (6), (7) and (8) can be thought of as involving a set of 'hurdles' which are encountered before an individual becomes self-employed. This interpretation would involve

$$
i_{j}^{*}=b_{j} X+\varepsilon_{j} \quad j=1,2,3
$$

where $\varepsilon_{1}, \varepsilon_{2}$ and $\varepsilon_{3}$ are independent standard normals. Now an individual is not interested if $i_{1}^{*}>0$, is latent if $i_{1}^{*} \leq 0$ and $i_{2}^{*}>0$, is potential if $i_{1}^{*} \leq 0$ and $i_{2}^{*} \leq 0$ and $i_{3}^{*}$ $>0$, and is self-employed if $i_{1}^{*} \leq 0$ and $i_{2}^{*} \leq 0$ and $i_{3}^{*} \leq 0$. It is important to note that the model allows for the importance of any given variable to differ from one 'hurdle' to the next. The same is not true if the ordered probit model is considered as a means of explaining the status of an individual. In the ordered probit model there is a single index function

$$
i^{*}=b X+\varepsilon
$$

and an individual is not interested if $i^{*}<0$, is latent if $0 \leq i^{*}<c_{1}$, is potential if $c_{1} \leq$ $i^{*}<c_{2}$, and is self-employed if $i^{*} \geq c_{2}$. In the ordered probit framework only the relationship between variables in $X$ and $P$ (not interested) and $P$ (self employed) can be determined given the $b$ vector $^{\text {vii }}$. Overall, it is perhaps best to think of the latent and potential categories as essentially stages implied by the process of becoming selfemployed with no particular policy issues arising over and above those associated with a probit view of the process ${ }^{\text {viii }}$. Indeed it might be argued that there is little 
benefit to the disaggregation of the non-self employed within the ordered probit framework. The same is not the case when the sequential approach is adopted ${ }^{\mathrm{ix}}$.

\section{DATA AND VARIABLES}

As part of the preparatory work for its Business Birth-rate Strategy ${ }^{x}$ Scottish Enterprise commissioned the MORI organisation to undertake interviews with representative samples of individuals, aged 15 or over, in Britain ${ }^{\mathrm{xi}}$. The data were weighted to match the known profile of the population. The initial sample of 2048 individuals was reduced to 2007 by excluding those who were unable to place themselves in an entrepreneurial group. Of the remainder, 1195 individuals were active in the labour market and the sample was reduced further to 947 when the unemployed were excluded. This paper follows the literature in this area and excludes the unemployed because the choice problem to be considered is solely between paidemployment and self-employment. The unemployed are clearly a source of potential entrepreneurs but the movement from unemployment to self-employment is in principle conceptually different compared to the movement from paid employment to self-employment.

The data set has several key attributes. First, as noted above, it allows the sample to be decomposed into four relevant sub-groups: the self-employed, potential entrepreneurs, latent entrepreneurs, and a not interested group. The employed labour force is taken as the relevant population ${ }^{\mathrm{xii}}$. 
Secondly, it allows variables to be constructed for inclusion in the $\boldsymbol{A}, \boldsymbol{X}$ and $\boldsymbol{Y}$ vectors of the models in sections 1 and 2 . We hypothesise that the potential for entrepreneurship will be influenced by 6 sets of explanatory variables: the objective human capital attributes of the individual; self-perceived human capital attributes; individual preferences towards self-employment; attitudes towards risk; a set of 'social' attitudes; and regional location. The 'social' attitudes are further decomposed into two sub-groups to distinguish what might be termed 'communitarian' or 'collectivist' views from 'individualistic' or 'self-reliant' attitudes. It is hypothesised that individuals whose social attitudes belong more to the former than the latter group will ceteris paribus have less interest in entrepreneurship and will therefore have a lower probability of becoming self employed.

For the objective human capital attributes $(\mathrm{OHC})$ of an individual we allow for a range of characteristics including, gender, age, socio-economic class, marital status, number of children, and entrepreneurial contacts. For the self-perceived human capital attributes (PHC) we allow for individuals' views on their dynamism, creativity, leadership skills, and ability to cope with pressure. Attitudes towards risk (RA) are measured by the stated willingness to take risks and the importance of job security. Preferences towards entrepreneurship and self-employment (PFE) are measured by the desire for independence and the priority placed on earning money. In addition, respondents were also asked about their newspaper readership and their views on the contribution made to society of a range of occupations including bankers, directors, lawyers, teachers, plumbers, bus drivers and ministers of religion. Positive social attitudes towards bus drivers, ministers, and teachers coupled with readership of leftof-centre broadsheet newspapers were assigned to the 'communitarian' group (SA1). 
Positive social attitudes towards bankers, directors, lawyers, and plumbers coupled with readership of centre or right-of-centre tabloid newspapers were assigned to the 'individualistic' group (SA2). Finally, individuals are assigned to 11 UK Standard regions which may be aggregated to broader regional locations $(\mathrm{L})$ depending on the acceptability of the required restrictions - see Appendix. Four broad regional groupings or 'super' regions are created to mark significant hypothesised differences in the degree of regional economic opportunity for self employment. The choice is loosely based on a core-adjacent-periphery approach - see Brand (2003), for a rigorous application of such an approach. In our classification London and the South East constitute the core, the South West, East Anglia and East Midlands comprise the adjacent, intermediate regions, and two peripheral groupings: an inner region: West Midlands, North West, Yorkshire \& Humberside and an outer area: Scotland, North and Wales. The restrictions imposed on the estimation in adopting this procedure are briefly discussed in Appendix 1. Table 1 provides descriptors and definitions of the variables used in the estimation.

\section{TABLE 1 HERE}

The uniqueness of the dataset is tempered somewhat by some possible problems. First, some variables are not continuously observed, specifically the income and age of the respondent and the age of the respondent's children. The availability of income data in bands implies only the reduced-form version of the standard model (equation 4) can be estimated. Secondly, it is possible that some of the variables included under perceived human capital attributes, attitudes towards risk and preferences for self employment, while necessary for entrepreneurial success, may not discriminate between paid and self-employment because such attributes are also 
necessary in certain forms of paid employment. The management literature on leadership and executive development, suggests that willingness to take risks, puts work before family, copes with pressure, is dynamic, is creative, has leadership skills, and puts a high priority on making money, are highly valued by companies (Wright, 1996). However, while this may be correct, we would hypothesise that such attributes are more closely associated with, and are likely to be better rewarded in, selfemployment. And, the estimation provides a test of their significance in the selfemployment choice decision.

A third problem is that data on some potential influences, for example, liquidity constraints, and educational background were not collected in the survey. These variables have proved important in some studies (for example Gill, 1988; de Wit and van Winden, 1989) but not all studies (see Parker, 2004, Chapter 3). Unfortunately, we are not able to test directly for their importance in the present study. However, some of the variables used are close proxies. For example, age, offers some positive relationship to access to physical capital and some aspects of human capital, such as work experience and informal network building (Parker, 2004).

Fourthly, we noted above that it is usual in the literature to exclude the unemployed from the analysis. This is because while the unemployed are a source of potential entrepreneurs, the movement from unemployment to self-employment is in principle conceptually different compared to the movement from paid employment to self-employment. Moreover the data do not allow us to identify 'reluctant' entrepreneurs who would have preferred paid employment but cannot find such an opportunity, nor can we distinguish those who are drawn or 'pushed' into self 
employment due, for example, to inheriting a family business when in the absence of such an event they would have remained in paid employment.

Fifthly, there is a risk that attitudinal and perceptual variables may not be wholly exogenous to the self-employment choice decision. While the objective characteristics of the individual are unlikely to change as a result of that choice, this may not be the case with attitudes and perceptions, which may reflect ex post rationalisations of previous choices. We are not aware of any evidence that supports this contention but the risk of endogeneity suggests that one should be cautious when interpreting the results.

Finally, it might be argued that ideally a longitudinal, rather than a crosssectional, dataset is more appropriate to test hypotheses of self-employment choice that embrace a sequential process. If entrepreneurship is a dynamic process then analysis might be better served by a longitudinal dataset rather than the present crosssection dataset that appears to imply a stationary environment. While accepting this, it is worth noting that a cross-sectional exercise does not lack value and is still the norm in the literature. Longitudinal data sets are now being used (Belghitar and Parker, 2006) but we are not aware of one that features the key attributes of the present dataset. 


\section{4. ESTIMATION AND RESULTS}

Standard Model

We first estimate the reduced form probit for the self-employment/paid employment choice decision. Combining the standard regions to produce the 4 'super' regions described above requires imposing seven parameter restrictions to make three regional dummies - see Appendix - with the most peripheral 'super' region, Scotland, the North and Wales taken as the default. On the basis of a likelihood ratio statistic, $\chi^{2}$ $(7)=13.637[0.058]$, the restrictions are acceptable on statistical grounds. We therefore present, in Table 2, estimation results using 'super' rather than standard regions providing estimates only for those variables that are statistically significant ${ }^{\mathrm{xiii}}$. There are 15 such variables. From the objective human capital (OHC) set ten are significant: FEMALE, AGE5054, AGE5559, AGE6064, AGE65+, MARRIED, COHABIT, WIDSEPDIV, CHAGED4, and CHILD4. The two variables representing attitudes towards risk (RA) - RISKPRO, SECURITY - and the two variables indicating preferences towards self-employment (PFE) - MONEY, INDEP - are all significant. None of the self perceived human capital attributes (PHC) and none of the 'individualistic' attitudes (SA2) is significant, while only one of the 'communitarian' attitudes (SA1) BUSDRIV attains statistical significance. All the three 'super' region dummies are significant. ${ }^{\text {xiv }}$

\section{TABLE 2 HERE}

Hence, from the estimation, individuals who are above age 50, are not single, have been widowed, separated or divorced, have 4 or more children, live outside Scotland, the North and Wales, are willing to take risks, place a high priority on 
making money, like being independent, are more likely to be self employed. On the other hand, individuals who are female, have children between 9 and 10 years, consider job security to be important, and believe bus drivers contribute a great deal to society, are less likely to become self-employed.

The joint importance of each of the sets of variables defined in Table 1 can be assessed using a likelihood ratio test. The null hypothesis in each case excludes each variable in the set from the explanation of the self/paid employment decision. The results reported in Table 2 suggest that the self-perceived human capital (PHC) variables, the communitarian attitudes (SA1) variables and/or the individualistic attitudes (SA2) variables could be excluded in a restricted estimation. ${ }^{\mathrm{xv}}$ Further implications of the results in Table 2 emerge in the discussion below of marginal effects.

It is difficult to compare the results from the estimation of the reduced form of the standard model with estimates provided by others. This is because the studies differ by definition of dependent and explanatory variables. For example, many studies exclude certain sectors e.g. agriculture, professionals, and/or take a truncated set of the self employed such as males aged 16-64, or those who have at least one employee, (see Le, 1999). Nevertheless, some comparisons are possible. Our finding that females are less likely to be self-employed than males confirms the earlier results of de Wit \& van Winden (1989), de Wit (1993) and Blanchflower \& Oswald (1998). The likelihood that married individuals are more likely to start their own firms is supported by the findings of several studies, including Rees \& Shah (1986), Evans \& Leighton (1989), de Wit \& van Winden (1989), de Wit (1993) and Bernhardt (1994). For age, the evidence generally suggests a positive relationship with self-employment 
(Parker, 2004). We find no such simple relationship, which may in part reflect the fact that age data were only available to the study in bands. However, our finding that individuals who are above age 50 are more likely to be self-employed is supported by evidence on retirement and self-employment. This suggests that some employees switch into self-employment as they approach formal retirement and that employees are more likely to retire than the self-employed because of a statutory retirement age for employees (Parker, 2004, pp. 204-207).

Estimation of the standard model for the UK reveals that individuals living outside Scotland, the North and Wales are more likely to be self-employed. Many other studies have found variations in firm formation rates and self-employment across the UK regions (Storey and Johnson, 1987; Ashcroft, Love and Malloy, 1991; Keeble, Walker and Robson, 1993; Robson, 1998), with the north and west of Britain performing less well. Our study is no exception.

The finding that desire for independence is associated with self-employment has been found in several studies (Taylor, 1996; Hamilton, 2000) while some studies have found that a willingness to take risks, and a belief that job security is unimportant are positively related to self-employment (van Praag, 2002; Uusitalo, 2001), and at least one other study found no significant relationship (Tucker, 1988). But it should be noted that measurement and methodology differ in these studies from the present approach and we restate the possibility that some attitudes and perceptions might reflect an ex post rationalisation of earlier choices. 


\section{Sequential Model}

We repeat the above type of analysis for each of the stages in the sequential probit. $^{\text {xvi }}$

(i) Estimating $\mathrm{b}_{1}$ in $\mathrm{P}_{1}=\Phi\left(\mathrm{b}_{1} \mathrm{X}\right)=\mathrm{P}($ not interested $)$

Here 1 in the estimated probit corresponds to an individual being classified as not interested. An initial estimation suggests that individuals in all regions are more likely to be interested in starting a firm compared with the default region of Scotland, but only in London and in the South East is the difference significant. However, the aggregation from standard to 'super' regions is an acceptable simplification, $\chi^{2}(7)=$ 6.636 [0.468], and we concentrate on this case in the following - see Table 3 . In this Table the incorporation of 'super' regions into the estimation leads to the finding that there is a significantly greater likelihood of being interested in self-employment in London and the South East, and in the East Midlands, South West and East Anglia than in Scotland, North and Wales. Turning to a consideration of the effect of the nonregional variables, we find from the objective human capital (OHC) set three are significant - FEMALE, COHABIT, FAMENT. The two variables representing attitudes towards risk (RA) - RISKPRO, SECURITY - one of the self-perceived human capital variables (PHC) - CREATIVE - and the two variables indicating preferences towards self-employment (PFE) - MONEY, INDEP - are significant. None of the 'individualistic' attitudes (SA2) and the 'communitarian' attitudes (SA1) variables is significant. The same non-regional variables are statistically significant when standard regions are used in estimation. 


\section{TABLE 3 HERE}

The results suggest that individuals who are female, and place a high value on job security, are less likely to be interested in starting a firm. Conversely, unmarried individuals living with a partner, located in the London and the South East, or East Midlands, East Anglia and the South West, with a family member who is an entrepreneur, a willingness to take risks, a perception of themselves as creative, a liking for independence, and placing a high priority on making money, are more likely to be interested in starting a firm.

The results of the tests of the joint importance of each of the sets of variables, suggest that the self-perceived human capital (PHC) variables and the communitarian attitudes (SA1) and individualistic attitudes (SA2) variables could be excluded from the estimation.

(ii) Estimating $\mathrm{b}_{2}$ in $\mathrm{P}_{2}=\left(1-\Phi\left(\mathrm{b}_{1} \mathrm{X}\right)\right) \Phi\left(\mathrm{b}_{2} \mathrm{X}\right)=\mathrm{P}($ Latent $)$

Here 1 in the estimated probit corresponds to an individual being classified as latent with the not interested excluded from the estimation ${ }^{\mathrm{xvii}}$. Using the standard regions the following variables are significant: SCLASSC1, WIDSEPDIV, SECURITY, and LAWYER. Moving to 'super' regions is acceptable on the basis of $\chi^{2}(7)=4.934[0.668]$ and leads to a further non-regional variable attaining significance SCLASSAB - see Table 4. The results suggest that from those interested in self employment, individuals who put a high value on job security are less likely to 
have a business idea, while those who are members of social classes $\mathrm{A} / \mathrm{B}$ and $\mathrm{C} 1$, are widowed, separated or divorced, and who believe that lawyers contribute a great deal to society, are more likely to have an idea for a new business. Although not included in Table 4, due to their insignificance, the regional coefficients all suggest a higher likelihood of having a business idea outside Scotland, North and Wales.

The tests of the joint importance of each of the sets of variables indicate that only the objective human capital (OHC), locational (L) and attitudes to risk (RA) variables are jointly significant.

\section{TABLE 4 HERE}

(iii) Estimating $\mathrm{b}_{3}$ in $\mathrm{P}_{3}=\left(1-\Phi\left(\mathrm{b}_{1} \mathrm{X}\right)\right)\left(1-\Phi\left(\mathrm{b}_{2} \mathrm{X}\right)\right) \Phi\left(\mathrm{b}_{3} \mathrm{X}\right)=\mathrm{P}($ Potential $)$

Here 1 in the estimated probit corresponds to an individual being classified as potential and the not interested and latent groups are excluded from the estimation. The statistic $\chi^{2}(7)=16.368\left([0.022]^{*}\right.$ suggests that the 'super' regions may not be an appropriate construction in this case. Accordingly, we present the results for estimation using standard regions - see Table 5. From the objective human capital (OHC) set nine variables - AGE2124, AGE4044, AGE5054, AGE5559, AGE60+, SCLASSAB, CHAGED4, 3CHILD, 4CHILD - are significant. Further, two of the standard regions - the North, Yorkshire \& Humberside - one of the two RA variables SECURITY - and two of the SA1 variables - BUSDRIV, BSPAPER - and two of the SA2 variables - DIRECTOR, PLUMBER - are also significant. The results suggest that from the set of potential and actual self-employees, individuals who have children 
TABLE 5 HERE

Comparing Standard and Sequential Models

The key statistical point is that these two models are non-nested meaning that neither model can be obtained from the other by imposing parameter restrictions. This implies there is no straightforward test procedure that can be used to discriminate between the two models. We have to decide on the relative merits of the two models in indirect ways. 
Predictive Success in the Two Models

The probabilities that constitute the sequential model can be evaluated using the parameter estimates reported in the tables. Making predictions according to the maximum estimated probability produces the results:

\begin{tabular}{|c|cccc|}
\hline & NI & L & P & SE \\
\cline { 2 - 5 } Not Interested & $\mathbf{4 7 4}$ & 6 & 19 & 36 \\
Latent & 105 & $\mathbf{1 1}$ & 8 & 10 \\
Potential & 70 & 8 & $\mathbf{1 7}$ & 13 \\
Self Employed & 97 & 6 & 6 & $\mathbf{6 1}$ \\
\hline
\end{tabular}

where the rows are actual classifications and the columns are predicted classifications. A clear implication is that the model displays a marked tendency to over predict the number of individuals in the not interested (NI) group while under predicting particularly membership of the latent (L) group.

For comparison with the standard model we have:

\begin{tabular}{|c|cc|cc|}
\hline \multirow{2}{*}{ Self Employment } & \multicolumn{2}{|c|}{ Sequential Model } & \multicolumn{2}{c|}{ Standard Model } \\
\cline { 2 - 5 } & SE & PE & SE & PE \\
Paid Employment & 31 & 131 & $\mathbf{3 9}$ & 131 \\
& 39 & $\mathbf{7 4 6}$ & 28 & $\mathbf{7 4 9}$ \\
\hline
\end{tabular}

where the rows are actual classifications and the columns are predicted classifications. The comparison reveals that the results are similar in the two models, but with both under predicting the number of self-employed. ${ }^{\text {xix }}$ 


\section{Marginal Effects}

In the standard model the probability of self-employment is given by

$$
\mathrm{P}=\Phi(\mathrm{bX})
$$

and the rate of change of $P$ with respect to $X_{j}$ is $b_{j} \phi(b X)$, where $X_{j}$ is element $j$ of $X$ and $b_{j}$ is element $j$ of $b . b_{j} \phi(b X)$ is the marginal effect if $X_{j}$ is a continuous variable. Since all our explanatory variables are dummies, however, it is more appropriate to calculate the value of (the estimated) $\mathrm{P}$ for different $\mathrm{X}$ vectors. In either case, there is an increasing relationship between the estimated probability of self-employment and the value of an explanatory variable if and only if the estimated parameter attached to that explanatory variable is positive.

In the sequential model the probability of self-employment is

$$
\mathrm{P}=\left(1-\Phi\left(\mathrm{b}_{1} \mathrm{X}\right)\right)\left(1-\Phi\left(\mathrm{b}_{2} \mathrm{X}\right)\right)\left(1-\Phi\left(\mathrm{b}_{3} \mathrm{X}\right)\right)=\Phi\left(-\mathrm{b}_{1} \mathrm{X}\right) \Phi\left(-\mathrm{b}_{2} \mathrm{X}\right) \Phi\left(-\mathrm{b}_{3} \mathrm{X}\right)
$$

The marginal effect for a continuous variable, $X_{j}$, is defined to be the rate of change of $P$ with respect to $X_{j}$. It is straightforward to obtain the expression

$$
-\left(\left(b_{1}\right)_{j} \lambda\left(-b_{1} X\right)+\left(b_{2}\right)_{j} \lambda\left(-b_{2} X\right)+\left(b_{3}\right)_{j} \lambda\left(-b_{3} X\right)\right) P
$$


where $\left(b_{i}\right)_{j}, i=1,2,3$, is the element of $b_{i}$ associated with variable $X_{j}$, and $\lambda=\phi / \Phi$. The sign of this expression is ambiguous in general but we can note: the probability of self employment increases as the value of $\mathrm{X}_{\mathrm{j}}$ increases if $\left(\mathrm{b}_{1}\right)_{\mathrm{j}},\left(\mathrm{b}_{2}\right)_{\mathrm{j}}$, and $\left(\mathrm{b}_{3}\right)_{\mathrm{j}}$ are all negative, whereas the probability of self employment decreases as the value of $\mathrm{X}_{\mathrm{j}}$ increases if $\left(b_{1}\right)_{j},\left(b_{2}\right)_{j}$, and $\left(b_{3}\right)_{j}$ are all positive. In these cases, the sign of the expression in (10) is unambiguous whilst its numerical value depends on the $\mathrm{X}$ vector and is not constant. The same comments apply in the case of a discrete explanatory variable but the analytical expression in (10) doesn't apply and we need to calculate the estimated value of $\mathrm{P}$ for different $\mathrm{X}$ vectors.

It is possible to use the estimations that constitute the sequential probit to deduce a negative relationship between the probability of self employment and the variables: FEMALE, SECURITY, and a positive relationship between the probability of self employment and the variables: AGE3034, AGE4044, MARRIED, WIDSEPDIV, NW, YH, EM, WM, SW, EA, LO, SE, FAMENT, 3CHILD, 4CHILD, RISKPRO, which conclusions agree with the results of the standard probit. As far as the other variables are concerned it is not possible to deduce the direction of the relationship between the variables and the probability of self-employment on the basis of the estimations that make up the sequential model. It is conceivable that the direction of the relationship changes as the $\mathrm{X}$ vector changes.

Table 6 presents the results of a set of marginal experiments for the standard and sequential probits. ${ }^{\mathrm{xx}}$ These experiments offer some interesting comparisons both within and between the two models. The estimated probability of self-employment for 
females is only about $56 \%$ of that for males in the standard model and about $70 \%$ in the sequential model. Members of socio-economic groups D and E are according to the standard model around 39\%, 37\% and 17\% less likely to be self-employed than members of groups $\mathrm{A} / \mathrm{B}, \mathrm{C} 1$ and $\mathrm{C} 2$, respectively. According to the sequential model, the percentages are $48 \%, 38 \%$ and $23 \%$, respectively. Married people are just under three and a half times in the standard model, and approaching three times in the sequential model, more likely than single individuals to be self-employed. The comparison is not much different for those who live together, while those who are widowed, separated or divorced are, in the standard model, more than four and a half times, and in the sequential model over four times, more likely than single people to be self-employed.

When attitudes towards risk are considered there are clear differences in the probability of self-employment. Individuals who indicate a willingness to take risks (RISKPRO) are in both models more than one and a half times as likely to be selfemployed. Again in both models those for whom job security is not important (SECURITY) are more than two and a half times as likely to be self-employed. For, individuals placing a high priority on making money and having a desire for independence (MONEY and INDEP) self employment is around one and a half times more likely in both models.

\section{TABLE 6 HERE}

Table 6 also presents the estimated probability of self-employment across the standard regions of Britain. For the standard model the estimated probability is the same for regions within any given 'super' region due to the acceptability of the appropriate restrictions. Across the 'super' regions the estimated probability of self- 
employment varies from a low of around $5 \%$ for $\mathrm{SC}+\mathrm{NO}+\mathrm{WA}$ to a high of around $16 \%$ for $\mathrm{EM}+\mathrm{SW}+\mathrm{EA}$. In the sequential model the estimated probability is allowed to vary within 'super' regions. The variation is most notable in $\mathrm{SC}+\mathrm{NO}+\mathrm{WA}$ with a probability of around $1 \%$ in WA, $7 \%$ in SC and $18 \%$ in the North. In NW+YH+WM the estimated probability is around $20 \%$ in both NW and YH but only around $10 \%$ in WM. In the other two 'super' regions there is in fact little variation across constituent standard regions. Overall, probabilities are close to $20 \%$ except in WA, SC and WM. Of course, in the sequential model the variation in probabilities for regions within super regions is due to the start-up stage where probabilities vary due to the 'super' region restrictions being unacceptable. These results are shown in the relevant rows of Table 7.

A final point worthy of note is that the sequential model almost invariably gives a higher estimated probability of self employment than the standard model. In some cases (FEMALE, WIDSEPDIV, INDEP = 0) the difference is quite substantial.

In the sequential model, the probability of self-employment is the product of the probabilities of being interested, having a feasible business idea when interested, and starting a firm given an idea and interest. Table 7 presents each component probability for the marginal experiments of Table 6. The table reveals differences in the importance of each component to changes in the probability of self-employment. For example, females are found to have a lower probability of self-employment than males because their probability of interest is much lower (75\% of males) than their probability of having a business idea (96\%) and their probability of translating their interest and ideas into action $(97 \%)^{\mathrm{xxi}}$. Similarly, individuals who are willing to take 
risks (RISKPRO) have a higher probability of self-employment principally because their probability of interest is higher (132\%). The probabilities of having an idea $(115 \%)$ and translating this into action (112\%) are much closer to those who perceive themselves as less willing to take risks. Much the same situation is found with the variables indicating preferences for self-employment. For interest, those who place a high priority on making money (MONEY) and who like to be independent (INDEP) have probabilities that are $151 \%$ and $143 \%$ of those with opposite preferences. The ratios of the probabilities for ideas are, however, only $108 \%$ and $112 \%$ for the two variables, respectively, and $99 \%$ and $89 \%$ for the ratio of the probabilities for translating ideas into action.

For socio-economic group and marital status, the impact on the probability of self-employment has much less to do with interest and much more to do with higher probabilities for ideas and action. Indeed, members of socio-economic group A/B have a lower probability of interest than members of the D/E group (82\%) but a higher probability both for ideas (138\%) and for the translation of ideas into action (170\%). This finding would appear to support the intuition that members of the $\mathrm{A} / \mathrm{B}$ group have comparative advantages in certain paid-employment occupations e.g. the professions, which lowers their interest in self-employment. On the other hand, for those in this group who are interested, their education, experience and skills, raise the likelihood of having a feasible business idea and equips them better to overcome the obstacles to start-up. For marital status, an interesting finding concerns the widowed, separated and divorced group (WIDSEPDIV). This group has much the same probability (114\%) as other single people to be interested but are more likely to have an idea (167\%) and much more likely, once interested, to start a firm (224\%). It is 
difficult to be certain, why this should be so, but it could reflect the greater possible access to capital of the widowed, although this would be less likely to apply to the separated and divorced. Older age and contacts might also favour this group compared to other single individuals. Again, the experience of becoming, widowed, separated or divorced might act as a trigger for individuals who have considered self-employment to make a career change; or the propensity to act on a business idea might reflect the presence of character traits that raise the likelihood of becoming separated or divorced. $^{\text {xxii }}$

For the importance of job security (SECURITY) the impact on self-employment reflects differences on all three component probabilities.

Finally, Table 7 allows us to consider variations in probabilities across the standard regions of Britain and between 'super' regions. Notice, by construction, within a 'super' region the only probability that is allowed to differ is that of start up. The differences are substantial in Scotland, the North and Wales, where the probability of a start up in Wales is only about $6 \%$ of that in the North. Conversely, in London and the South East the start up probabilities are essentially identical. In the other two cases both East Midlands and West Midlands have probabilities that are noticeably lower than the other members of their super region. For the 'super' regions as a whole, Scotland, the North and Wales ranks bottom and the North West, Yorkshire \& Humberside and West Midlands ranks second bottom at both the interest and ideas stage. However, for the other two regions the ranking varies between interest and ideas stages.

\section{TABLE 7 HERE}




\section{CONCLUSIONS}

In this paper we have estimated a model of self-employment choice that has frequently been employed in the literature. The model was extended to allow for differences in the potential for self-employment within the employed group of the labour force. Three particular sub-groups were identified: the not interested; latent entrepreneurs, that is, those interested in starting a firm but who believe that they do not have an appropriate idea; and potential entrepreneurs, that is, those interested in setting up, who consider that they have a suitable idea but who, for whatever reason, have not yet 'taken the plunge'. We noted that such a decomposition could be modelled either as a sequential probit, or as an ordered probit. However, we took the view that a sequential approach was to be preferred on a priori grounds.

The predictive performance of the standard and sequential models was similar, as both models tended to under predict the number of self-employed, although the sequential model invariably gave a higher estimated probability of self-employment than the standard model. We believe that the sequential model offers some distinct advantages over the standard model. In separating out the determinants of interest from the idea and start-up decisions, the model identifies a set of characteristics that are necessary for start-up i.e. the factors determining interest, but which are not sufficient. In the standard model, the necessary and sufficient conditions are assumed to be identical. So, for example, while the standard model suggests that females are significantly less likely to set-up their own firm, the sequential model reveals that females are less likely to be interested in self-employment than males, but are no less 
likely once interested to translate that interest into action. Similar comments apply to individuals living together, willing to take risks, placing a high priority on making money, and wishing to be independent. Such individuals are more likely to start a firm in the standard model but in the sequential model are more likely to be interested in starting a firm while being no less likely once interested to start-up. At the regional level the unacceptability of the restrictions in the sequential model at the start-up stage reveals significant differences in probabilities within 'super' regions especially in Scotland, the North, and Wales. In the standard model, individuals in East Midlands, the South West, and East Anglia have a higher probability of start-up (16\%) than in London and the South East (15\%), the North West, Yorkshire \& Humberside, and the West Midlands (12\%), and Scotland, the North, and Wales (5\%). But in the sequential model at the level of the 'super' region while Scotland, the North, and Wales ranks bottom and the North West, Yorkshire \& Humberside, and the West Midlands ranks second bottom at both the interest and ideas stages, for the other two 'super' regions the ranking varies between the interest and ideas stages.

The results also offer some support for our earlier contention of the importance of attitudes, preferences and perceptions towards self-employment, and the necessity for entrepreneurial vision. Measures of attitudes towards risk were important in the standard model and in the sequential model both to the stimulation of interest and to the actual start-up decision. Our findings also underline the view present in the psychology literature of the importance to potential entrepreneurship of motivation (Shapero, 1975) and perceptions of self-efficacy (Kreuger and Brazeal, 1994). However, the proxies for self-perception and motivation that were significant in the estimation of the sequential model contribute primarily to the determination of interest 
and not to the decision to set-up from within the interested or potential group. Whether potential entrepreneurs translate their interest into action appears to depend crucially on the objective human capital attributes of individuals, their location and attitudes towards risk, which conform to the more traditional economics interpretation of the start-up process.

Finally, our findings do appear to have implications for regional policy. There appears to be a clear distinction between the factors governing interest in entrepreneurship and those influencing start-up. Regional policy makers seeking to raise the business birth rate need, therefore, to take account of this finding. Moreover, while the stimulation of interest appears to be important in raising the pool of potential entrepreneurs, it is not sufficient to ensure start-up. Policies are required both to stimulate interest and to assist in the translation of interest into action, and different groups may be the focus of one, or both, of the two types of policy. Policy cannot, of course, influence all the determinants of interest and start-up but some may be subject to policy influence. So, Scottish Enterprise's Business Birth Rate Strategy put an initially greater emphasis on policies designed to influence culture and attitudes towards entrepreneurship compared to policies that sought to make the process of business start-up easier ${ }^{\text {xiii }}$. In devising means to improve the process of start-up policy needs to confront the risk aversion that appears to hold back many would-be entrepreneurs in the UK and seek to provide compensation for a lack of experience in running a business. ${ }^{\text {xxiv }}$ 


\section{REFERENCES}

AMEMIYA, T., (1975), 'Qualitative Models', Annals of Economic and Social Measurement, 4, pp363-372.

AMIT, R., GLOSTEN, L. and MULLER, E. (1993), 'Challenges to theory development in entrepreneurial research', Journal of Mathematical Sociology, 30, pp. 815-834.

ASHCROFT, B K, LOVE J H, and MALLOY E, (1991) 'New Firm Formation in the British Counties with special reference to Scotland', Regional Studies, 25, 5, 395-409

BELGHITAR, Y. and PARKER S, (2006) 'What Happens to Nascent Entrepreneurs?', Small Business Economics, Vol. 27, pp. 81-101.

BERNHARDT, I (1994), 'Comparative Advantage in Self-employment and Paid Work', Canadian Journal of Economics, 27, 273-289.

BLANCHFLOWER, D. G., MEYER, B. D.,(1994), 'A Longitudinal Analysis Of The Young Self-Employed In Australia And The US', Small Business Economics, 6, 1-19.

BLANCHFLOWER, D. G., OSWALD, A. J., (1998), 'What Makes An Entrepreneur? Labour Economics 7, 471-505

BLANCHFLOWER, D. G., OSWALD, A. J., and STUTZER, A. (2001) 'Latent entrepreneurship across nations', European Economic Review, 45, pp. 680-691. 
BLAU, D., (1985), 'Self-Employment and Self-Selection in Developing Country Labor Markets', Southern Economic Journal, 52, 351-363

BLAU, D., (1987), 'A Time Series Analysis of Self Employment In The United States', Journal Of Political Economy, 95, 445-467.

BRAND, H, J, E, M (2003), “A Regional Core, Adjacent, Periphery Model for National Economic Geography Analysis", Department of Economics, Working Paper 2004/1, University of Glasgow.

CLARK, K., DRINKWATER, S. (2000) 'Pushed out or pulled in? Self-employment among ethnic minorities in England and Wales', Labour Economics, 7, pp. 603-628.

DOLTON, P. J., MAKEPEACE, G. H., (1990), 'Self Employment Among Graduates', Bulletin Of Economic Research, 42, 1, 35-53.

EVANS, D., JOVANOVIC, B., (1989), 'An Estimated Model Of Entrepreneurial Choice Under Liquidity Constraints', Journal Of Political Economy, 97, 808-827.

EVANS, D., LEIGHTON, L., (1989), 'Some Empirical Aspects Of Entrepreneurship', American Economic Review, 79, 519-535.

GILL, A. M., (1988), 'Choice Of Employment Status And The Wages Of Employees And The Self Employed: some further evidence', Journal Of Applied Econometrics, 3, 229-234. 
GOLDBERGER, A. (1983) 'Abnormal Selection Bias', in S. Karlin, T. Amemiya, and L. Goodman (eds.) Studies in Econometrics, Time Series and Multivariate Statistics, New York: Academic Press.

HAMILTON, B. H. (2000) 'Does entrepreneurship pay? An empirical analysis of the returns to self-employment.' Journal of Political Economy, 108, pp.604-631.

HECKMAN, J., (1979), 'Sample Selection Bias As A Specification Error', Econometrica, 47, 153-161.

KEEBLE, D. WALKER, S. and ROBSON, M. (1993), 'New Firm Formation and Small Business Growth: Spatial and Temporal Variations and Determinants in the United Kingdom', Employment Department Research Series, 15, London, HMSO.

KIHLSTROM, R., LAFFONT, J (1979) 'A General Equilibrium Entrepreneurial Theory of Firm Formation Based on Risk Aversion', Journal of Political Economy, 87, 719-748.

KRUEGER, Jr, N. F., BRAZEAL, D. V., (1994), 'Entrepreneurial Potential And Potential Entrepreneurs', Entrepreneurship Theory \& Practice, 18, 3, Spring, 91-104.

KNIGHT, F, (1921), Risk, Uncertainty and Profit, Boston, Houghton Mifflin.

KIRZNER, I, (1973), Competition and Entrepreneurship, Chicago, University of Chicago Press.

KIRZNER, I, (1979), Perception, Opportunity and Profit, Chicago, University of Chicago Press. 
LE, A. T. (1999), 'Empirical Studies of Self Employment', Journal of Economic Surveys, 13, pp. $381-416$

LUCAS R, (1978) 'On the Size Distribution of Business Firms', Bell Journal of Economics, 9, 508-523.

MADDALA, G. S., (1983), Limited-Dependent And Qualitative Variables In Econometrics, Cambridge, Cambridge University Press.

NATIONAL ASSEMBLY OF WALES (2002), A Winning Wales: The National Economic Development Strategy of the Welsh Assembly Government

PARKER S. C. (2004), The Economics of Self-Employment and Entrepreneurship, Cambridge, Cambridge University Press

PRAAG, C. M. van, CRAMER, J. S. and HARTOG, J. (2002), 'Low risk aversion encourages the choice for entrepreneurship: an empirical test of a truism', Journal of Economic Behavior and Organization, 48, pp. 29-36.

REES, H., SHAH, A., (1986), 'An Empirical Analysis Of Self-Employment In The UK', Journal of Applied Econometrics, 1, 95-108.

ROBSON, M. T. (1998), 'Self-employment in the UK regions', Applied Economics, 30, pp. 313-322. 
SCOTTISH ENTERPRISE, (1992), Scotland's Business Birth Rate, Glasgow, Scottish Enterprise \& Scottish Business Insider.

SCHUMPETER, J A (1950), Capitalism, Socialism and Democracy,, $3^{\text {rd }}$ Ed., New York, Harper Row.

SHAPERO, A, (1975) 'The Displaced, Uncomfortable Entrepreneur', Psychology Today, 9, November, 83-88 \& 133.

STOREY, D J, JOHNSON, S, (1987), 'Regional Variations in Entrepreneurship in the UK', Scottish Journal of Political Economy, 34, 161-173.

TAYLOR, M. P. (1996), 'Earnings, independence or unemployment: why become self-employed?' Oxford Bulletin of Economics and Statistics, 58, pp. 253-266.

TUCKER, I. B. (1988), 'Entrepreneurs and public sector employees: the role of achievement motivation and risk in occupational choice', Journal of Economic Education, 19, pp. 259-268.

UUSITALO, R. (2001), 'Homo entreprenaurus?' Applied Economics, 33, pp. 31-36.

WIT, de G, (1993), Determinants of Self Employment, Studies in Contemporary Economics, Heidelberg, Physica-Verlag.

WIT de G, WINDEN F van, (1989) 'An Empirical Analysis of Self-Employment in the Netherlands'. Small Business Economics, 1, 263-272. 
WIT de G, WINDEN F van, (1990) 'An Empirical Analysis of Self-Employment in the Netherlands', Economic Letters, 32, 97-100.

WRIGHT, P. (1996) Managerial Leadership, London: Routledge. 


\section{Appendix - Regions and 'Super' regions}

Moving from10 regional dummies to 3 'super' regional dummies ought to produce seven restrictions. The restrictions are as follows: if

$$
\gamma_{1} D_{1}+\gamma_{2} D_{2}+\gamma_{3} D_{3}+\gamma_{4} D_{4}+\gamma_{5} D_{5}+\gamma_{6} D_{6}+\gamma_{7} D_{7}+\gamma_{8} D_{8}+\gamma_{9} D_{9}+\gamma_{10} D_{10}
$$

is the starting point then the two restrictions $\gamma_{2}=\gamma_{3}=\gamma_{5}$ makes one 'super' region of regions 2, 3, and 5, the two restrictions $\gamma_{4}=\gamma_{7}=\gamma_{8}$ makes one 'super' region of regions 4,7 , and 8 , and the single restriction $\gamma_{9}=\gamma_{10}$ makes the final 'super' region of regions 9 and 10. The five restrictions above give

$$
\gamma_{1} D_{1}+\gamma_{2}\left(D_{2}+D_{3}+D_{5}\right)+\gamma_{4}\left(D_{4}+D_{7}+D_{8}\right)+\gamma_{6} D_{6}+\gamma_{9}\left(D_{9}+D_{10}\right)
$$

and then the two restrictions $\gamma_{1}=\gamma_{6}=0$ are required to ensure the default 'super' region is made up of regions 0,1 , and 6 . 
Table 1: Definition of Variables Used in the Estimation

\begin{tabular}{|c|c|c|c|}
\hline Variable & Description & Variable & Description \\
\hline \multicolumn{2}{|c|}{ Objective Human Capital (OHC) } & \multicolumn{2}{|c|}{ Location (L)-Restricted } \\
\hline FEMALE & female & $\mathrm{NW}+\mathrm{YH}+\mathrm{WM}$ & N. West/Y \& H/W. Midlands \\
\hline Default & male & $\mathrm{EM}+\mathrm{SW}+\mathrm{EA}$ & E. Midlands/S. West/E. Anglia \\
\hline AGE2124 & $21-24$ & $\mathrm{LO}+\mathrm{SE}$ & London/S. East \\
\hline AGE2529 & $25-29$ & $\begin{array}{l}\text { Default }= \\
\mathrm{SC}+\mathrm{NO}+\mathrm{WA}\end{array}$ & Scotland/North/Wales \\
\hline AGE3034 & $30-34$ & \multicolumn{2}{|c|}{ Attitudes to Risk $(R A)^{+}$} \\
\hline AGE3539 & $35-39$ & RISKPRO & Willing to take risks \\
\hline AGE4044 & $40-44$ & SECURITY & job security is important \\
\hline AGE4549 & $45-49$ & \multicolumn{2}{|c|}{${\text { Self-Perceived Human Capital }(P H C)^{+}}^{+}$} \\
\hline AGE5054 & $50-54$ & CARES & cares for people \\
\hline AGE5559 & $55-59$ & COPES & Copes with pressure \\
\hline AGE6064 & $60-64$ & WORKFAM & puts work before family \\
\hline AGE65+ & $65+$ & DYNAMIC & Dynamic \\
\hline Default & $15-20 y r s$ & CREATIVE & Creative \\
\hline SCLASSAB $^{\wedge}$ & social class $\mathrm{A} / \mathrm{B}$ & LEADER & has leadership skills \\
\hline SCLASSC1 & social class $\mathrm{C} 1$ & \multicolumn{2}{|c|}{ Preferences for Self Employment $(P F E)^{+}$} \\
\hline SCLASSC2 & social class $\mathrm{C} 2$ & MONEY & high priority on making money \\
\hline Default & social class $\mathrm{D} / \mathrm{E}$ & INDEP & likes being independent \\
\hline MARRIED & married & \multicolumn{2}{|c|}{ 'Communitarian' Attitudes (SA1) } \\
\hline COHABIT & live together & BUSDRIV* & bus driver \\
\hline WIDSEPDIV & widowed/div/separated & MINISTER ${ }^{*}$ & Minister of religion \\
\hline Default & single & TEACHER ${ }^{*}$ & Teacher \\
\hline CHAGED $^{\#}$ & $0-4$ years & LWPAPER & Reads left wing paper \\
\hline CHAGED2 & $5-6$ years & BSPAPER & Reads broadsheets \\
\hline CHAGED3 & $7-8$ years & \multicolumn{2}{|c|}{ Individualistic Attitudes (SA2) } \\
\hline CHAGED4 & $9-10$ years & BANKER $^{*}$ & Banker \\
\hline CHAGED5 & $11-14$ years & DIRECTOR ${ }^{*}$ & Director of large company \\
\hline Default & no children & LAWYER* & Lawyer \\
\hline 1CHILD & one child & PLUMBER ${ }^{*}$ & Plumber \\
\hline 2CHILD & two children & CPAPER & Reads centre paper \\
\hline 3CHILD & three children & RWPAPER & Reads right wing paper \\
\hline 4CHILD & four or more children & TABPAPER & Reads tabloids \\
\hline Default & no children & & \\
\hline KNOWENT & know an entrepreneur & & \\
\hline FAMENT & family member is & & \\
\hline \multicolumn{4}{|l|}{ Location $(L)$ - } \\
\hline \multicolumn{4}{|l|}{ Un Restricted } \\
\hline $\mathrm{NO}$ & North & & \\
\hline NW & North West & & \\
\hline $\mathrm{YH}$ & Yorks \& Humber & & \\
\hline EM & East Midlands & & \\
\hline WM & West Midlands & & \\
\hline WA & Wales & & \\
\hline SW & South West & & \\
\hline EA & East Anglia & & \\
\hline LO & London & & \\
\hline SE & South East & & \\
\hline Default $=\mathrm{SC}$ & Scotland & & \\
\hline
\end{tabular}

${ }^{\wedge}$ This is the Social Grade definition used by market researchers, which classifies on the basis of the occupation of the individual into one of six categories, A, B C1, C2, D or E. A's are professionals etc and the E's are those on lowest levels of subsistence. The ABC1's are sometimes termed 'middle class' and the C2DE's as 'working class'. ${ }^{+}$Self-perceived characteristics; * Contributes a great deal to society; for all attitudes categories; ${ }^{\text {\# }}$ CHAGED is children in the defined age groups. 
Table 2: Standard Model: Reduced Form Probit Equation for Self-Employment Choice

\begin{tabular}{|c|c|c|}
\hline Variable & Coefficient & t-ratio \\
\hline CONSTANT & -3.15121 & -7.10325 \\
FEMALE & -0.338398 & -2.62380 \\
AGE5054 & 0.903130 & 2.13782 \\
AGE5559 & 1.00459 & 2.29219 \\
AGE6064 & 1.13992 & 2.50232 \\
AGE65+ & 1.36419 & 2.37851 \\
MARRIED & 0.656390 & 2.71627 \\
COHABIT & 0.688090 & 2.38434 \\
WIDSEPDIV & 0.877470 & 2.97519 \\
CHAGED4 & -0.717804 & -2.50492 \\
CHILD4 & 1.52166 & 1.97839 \\
RISKPRO & 0.345867 & 2.71015 \\
SECURITY & -0.598717 & -5.09722 \\
MONEY & 0.402036 & 2.75192 \\
INDEP & 0.353325 & 2.58387 \\
BUSDRIV & -0.319201 & -2.15816 \\
NW+YH+WM & 0.435315 & 2.28456 \\
EM+SW+EA & 0.609846 & 2.94617 \\
LO+SE & 0.559101 & 2.97711 \\
\hline
\end{tabular}

Note: The table shows only those variables that achieve a significance level of at least $5 \%$. A full set of results including insignificant variables is available from the authors. Below, significance at 5\% (1\%) level is indicated by ${ }^{* * *)}$. Number of observations: 947, of which $170(18 \%)$ self-employed.

Likelihood Ratio Test Statistic for zero slopes is $189.642^{* *}$

Likelihood Ratio Test Statistics for groups of explanatory variables are:

OHC variables: $\chi^{2}(28)=87.042^{* *}$

L variables: $\chi^{2}(3)=11.358^{* *}$

RA variables: $\chi^{2}(2)=37.556^{* *}$

PHC variables: $\chi^{2}(6)=4.302$

PFE variables: $\chi^{2}(2)=13.374^{* *}$

SA1 variables: $\chi^{2}(5)=10.552$

SA2 variables: $\chi^{2}(7)=8.27$ 
Table 3: Sequential Model: Probit Equation for the Absence of Interest in Self Employment

\begin{tabular}{|c|c|c|}
\hline Variable & Coefficient & t-ratio \\
\hline CONSTANT & 0.929572 & 3.46295 \\
FEMALE & 0.312592 & 3.13002 \\
COHABIT & -0.526035 & -2.54753 \\
FAMENT & -0.320735 & -3.34908 \\
RISKPRO & -0.317427 & -3.09943 \\
SECURITY & 0.324704 & 3.49220 \\
CREATIVE & -0.288065 & -2.71087 \\
MONEY & -0.505416 & -4.05044 \\
INDEP & -0.366922 & -3.57583 \\
EM+SW+EA & -0.316114 & -2.02782 \\
LO+SE & -0.387378 & -2.82397 \\
\hline
\end{tabular}

Note: The table shows only those variables that achieve a significance level of at least $5 \%$. A full set of results including insignificant variables is available from the authors. Below, significance at $5 \%(1 \%)$ level is indicated by ${ }^{*}{ }^{* *}$. Number of observations: 947 , of which $535(56 \%)$ not interested in selfemployment.

Likelihood Ratio Test Statistic for zero slopes is $174.839^{*}$

Likelihood Ratio Test Statistics for groups of explanatory variables are:

OHC variables: $\chi^{2}(28)=52.876^{* *}$

L variables: $\chi^{2}(3)=8.548^{*}$

RA variables: $\chi^{2}(2)=23.972^{* *}$

PHC variables: $\chi^{2}(6)=12.176$

PFE variables: $\chi^{2}(2)=27.56^{* *}$

SA1 variables: $\chi^{2}(5)=4.29$

SA2 variables: $\chi^{2}(8)=9.796$ 
Table 4: Sequential Model: Probit Equation for Latent Entrepreneurs from those Interested in Self Employment

\begin{tabular}{|c|c|c|}
\hline Variable & Coefficient & t-ratio \\
\hline CONSTANT & 0.431943 & 0.951690 \\
SCLASSAB & -0.540585 & -2.05340 \\
SCLASSC1 & -0.503927 & -2.18609 \\
WIDSEPDIV & -1.36876 & -2.59759 \\
SECURITY & 0.503577 & 3.14584 \\
LAWYER & -0.412889 & -2.35119 \\
\hline
\end{tabular}

Note: The table shows only those variables that achieve a significance level of at least $5 \%$. A full set of results including insignificant variables is available from the authors. Below, significance at $5 \%(1 \%)$ level is indicated by ${ }^{*}{ }^{(*)}$. Number of observations: 412, of which $134(33 \%)$ classified to the latent group.

Likelihood Ratio Test Statistic for zero slopes is $93.732^{* *}$

Likelihood Ratio Test Statistics for groups of explanatory variables are:

OHC variables: $\chi^{2}(27)=53.61^{* *}$

L variables: $\chi^{2}(3)=4.564^{*}$

RA variables: $\chi^{2}(2)=14.7^{* *}$

PHC variables: $\chi^{2}(6)=3.68$

PFE variables: $\chi^{2}(2)=1.574$

SA1 variables: $\chi^{2}(5)=7.216$

SA2 variables: $\chi^{2}(7)=10.964$ 
Table 5: Sequential Model: Probit Equation for Potential Entrepreneurs from Potential and Actual Self Employees, with Unrestricted Regions

\begin{tabular}{|c|c|c|}
\hline Variable & Coefficient & t-ratio \\
\hline CONSTANT & 3.00830 & 3.37904 \\
AGE2124 & -1.20634 & -1.96220 \\
AGE4044 & -1.44642 & -2.00804 \\
AGE5054 & -2.27155 & -2.73908 \\
AGE5559 & -2.21667 & -2.75808 \\
AGE60+ & -2.75332 & -3.04687 \\
SCLASSAB & -0.919503 & -2.37527 \\
CHAGED4 & 1.42063 & 2.21630 \\
3CHILD & -2.64686 & -2.00596 \\
4CHILD & -4.18978 & -2.27211 \\
SECURITY & 0.689517 & 2.76401 \\
DIRECTOR & -0.589051 & -1.99160 \\
PLUMBER & -1.11812 & -3.71935 \\
BSPAPER & 1.15421 & 2.24795 \\
BUSDRIV & 0.670713 & 2.26588 \\
NO & -1.88819 & -2.14599 \\
YH & -1.18852 & -1.97574 \\
\hline
\end{tabular}

Note: The table shows only those variables that achieve a significance level of at least $5 \%$. A full set of results including insignificant variables is available from the authors. Below, significance at 5\% (1\%) level is indicated by ${ }^{*}{ }^{(*)}$. Number of observations: 278 , of which 108 (39\%) classified to the potential group.

Likelihood Ratio Test Statistic for zero slopes is $138.238^{* *}$

Likelihood Ratio Test Statistics for groups of explanatory variables are:

OHC variables: $\chi^{2}(27)=72.322^{* *}$

L variables: $\chi^{2}(10)=20.606^{*}$

RA variables: $\chi^{2}(2)=9.248^{* *}$

PHC variables: $\chi^{2}(6)=7.472$

PFE variables: $\chi^{2}(2)=0.504$

SA1 variables: $\chi^{2}(5)=11.246^{*}$

SA2 variables: $\chi^{2}(7)=23.522^{* *}$ 
Table 6: The Estimated Probability of Self Employment: Marginal Experiments with Standard and Sequential Models

\begin{tabular}{|l|c|c|}
\hline \multirow{2}{*}{ Individual is: } & \multicolumn{2}{|c|}{ Model } \\
\cline { 2 - 3 } & Standard & Sequential \\
\hline MALE & 0.1500 & 0.1977 \\
FEMALE & 0.0846 & 0.1377 \\
\hline SCLASSD/E & 0.0886 & 0.1154 \\
SCLASSAB & 0.1455 & 0.2210 \\
SCLASSC1 & 0.1406 & 0.1847 \\
SCLASSC2 & 0.1062 & 0.1491 \\
\hline SINGLE & 0.0426 & 0.0690 \\
MARRIED & 0.1435 & 0.1907 \\
COHABIT & 0.1508 & 0.1792 \\
WIDSEPDIV & 0.1994 & 0.2959 \\
\hline RISKPRO $=0$ & 0.0977 & 0.1412 \\
RISKPRO =1 & 0.1714 & 0.2396 \\
\hline SECURITY =0 & 0.2021 & 0.2843 \\
SECURITY =1 & 0.0759 & 0.1060 \\
\hline MONEY =0 & 0.1071 & 0.1569 \\
MONEY =1 & 0.2004 & 0.2522 \\
\hline INDEP $=0$ & 0.0770 & 0.1329 \\
INDEP $=1$ & 0.1419 & 0.1876 \\
\hline SC & 0.0545 & 0.0655 \\
\hline NO & 0.0545 & 0.1806 \\
\hline NW & 0.1215 & 0.1887 \\
\hline YH & 0.1215 & 0.2025 \\
\hline EM & 0.1604 & 0.1934 \\
\hline WM & 0.1215 & 0.0988 \\
\hline WA & 0.0545 & 0.0112 \\
\hline SW & 0.1604 & 0.2201 \\
\hline EA & 0.1604 & 0.2234 \\
\hline LO & 0.1483 & 0.2023 \\
\hline SE & 0.1483 & 0.2069 \\
\hline & & \\
\hline
\end{tabular}


Table 7: The Estimated Probability of Interest, Having A Business Idea and Start Up: Marginal Experiments with the Sequential Model

\begin{tabular}{|l|c|c|c|}
\hline \multirow{2}{*}{ Individual is: } & \multicolumn{3}{|c|}{ Sequential Model } \\
\cline { 2 - 4 } & Interest & Idea & Start Up \\
\hline MALE & 0.4781 & 0.6811 & 0.6073 \\
FEMALE & 0.3566 & 0.6546 & 0.5901 \\
\hline SCLASSD/E & 0.4640 & 0.5277 & 0.4713 \\
SCLASSAB & 0.3782 & 0.7291 & 0.8017 \\
SCLASSC1 & 0.4470 & 0.7168 & 0.5765 \\
SCLASSC2 & 0.4253 & 0.6581 & 0.5327 \\
\hline SINGLE & 0.3629 & 0.5584 & 0.3407 \\
MARRIED & 0.4347 & 0.6762 & 0.6487 \\
COHABIT & 0.5696 & 0.4788 & 0.6570 \\
WIDSEPDIV & 0.4143 & 0.9352 & 0.7636 \\
\hline RISKPRO =0 & 0.3849 & 0.6361 & 0.5768 \\
RISKPRO =1 & 0.5099 & 0.7305 & 0.6432 \\
SECURITY =0 & 0.5009 & 0.7663 & 0.7406 \\
SECURITY =1 & 0.3736 & 0.5883 & 0.4823 \\
MONEY =0 & 0.3945 & 0.6612 & 0.6015 \\
MONEY = 1 & 0.5939 & 0.7139 & 0.5948 \\
INDEP =0 & 0.3289 & 0.6186 & 0.6533 \\
INDEP =1 & 0.4697 & 0.6906 & 0.5783 \\
PLUMBER =0 & 0.4482 & 0.6733 & 0.4729 \\
PLUMBER =1 & 0.3786 & 0.6634 & 0.8531 \\
\hline SC & 0.3314 & 0.5867 & 0.3368 \\
NO & 0.3314 & 0.5867 & 0.9288 \\
NW & 0.4147 & 0.6272 & 0.7255 \\
YH & 0.4147 & 0.6272 & 0.7786 \\
EM & 0.4523 & 0.7538 & 0.5673 \\
WM & 0.4147 & 0.6272 & 0.3798 \\
WA & 0.3314 & 0.5867 & 0.0577 \\
SW & 0.4523 & 0.7538 & 0.6456 \\
EA & 0.4523 & 0.7538 & 0.6553 \\
LO & 0.4806 & 0.7062 & 0.6096 \\
SE & 0.4806 & 0.7062 & \\
\hline
\end{tabular}




\section{ENDNOTES}

${ }^{i}$ The data were constructed from the records of interviews with a representative set of 2,787 individuals in the UK conducted by the MORI organisation for Scottish Enterprise as part of work in connection with its Business Birth-rate Strategy.

ii The results from estimation of the ordered probit approach are not presented here but are available from the authors.

iii Some studies e.g. Rees and Shah (1986) have attempted to estimate the structural form of the 'standard' model where adequate earnings data are available.

${ }^{\text {iv }}$ For a review of the role of psychological characteristics in entrepreneurial research see Amit, Glosten and Muller (1993). They identify 4 psychological traits that have been the subject of much research interest: need for achievement, above-average risk taking propensity, internal locus of control, and a tolerance of ambiguity.

${ }^{\mathrm{v}}$ Of course this process may in many cases happen simultaneously but we believe it is analytically useful to view the process as sequential.

${ }^{\text {vi }}$ For example, if a variable has an associated negative in $b_{1}$ and a positive in $b_{2}$ an increase in the variable will increase $P$ (latent).

${ }^{\text {vii }}$ For example, an increase in a variable with a positive element in $b$ leads to a decrease in $P(\mathrm{NI})$ and an increase in $P(\mathrm{SE})$. The implications for $P(\mathrm{~L})$ and $P(\mathrm{P})$ are ambiguous.

viii The probit approach is recovered by aggregating the NI, L and P into a single group. Clearly, (9) is playing a similar role to (4) in the standard model.

${ }^{\text {ix }}$ Perhaps as a consequence Amemiya (1975, page 293) argues

"The use of the ordered model is less common in econometric applications than in biometric applications. This must be due to the fact that economic phenomena 
are complex and difficult to explain in terms of a single unobserved index variable."

However, the flexibility of the sequential approach comes at the cost of reduced degrees of freedom.

${ }^{\mathrm{x}}$ Launched in 1993.

${ }^{x i}$ A copy of the survey questions can be obtained from the authors.

${ }^{\text {xii }}$ Approximately $44 \%$ of the sample was interested in founding a firm, including 170 or $18 \%$ of the total, who had actually set up their own firm. Within the interested group, $33 \%$ could be classified as latent entrepreneurs and $26 \%$ as potential entrepreneurs. The remaining $41 \%$ of the interested group were actually running their own firm.

${ }^{\text {xiii }}$ Statistical significance is defined by an absolute ' $t$ ' in excess of 1.96 .

${ }^{\text {xiv }}$ When standard regions are used rather than 'super' regions the statistically significant non-location variables remain the same except for the disappearance of CHILD4 and the appearance of PLUMBER. Of the location variables only SW and LO are significant.

${ }^{\mathrm{xv}}$ The results of the restricted estimation are not presented here. The detailed results of all the estimations discussed in this paper can be obtained from the authors.

${ }^{x v i}$ For more details on the estimation of sequential probits see Madalla (1983, pp. 49$51)$.

${ }^{\text {xvii }}$ The reduced number of observations necessitated combining the AGE6064 and AGE65+ groups into a single group, AGE60+.

xviii The regions excluded on statistical significance grounds all have a greater likelihood of self employment than the default region Scotland, with the exception of 
Wales. This issue is considered further in the marginal experiments later in the paper. ${ }^{\text {xix }}$ See Maddalla (1983) pp. 76-77 for a discussion of comparing actual and predicted outcomes in this way.

${ }^{\mathrm{xx}}$ For example, in the first block we compare MALE to FEMALE, with all other explanatory variables set at the sample average. The estimation of the standard model features 'super' regions, hence the constancy of the reported probability across the constituent standard regions evident in Table 6 - see for example the SC, NO, and WA rows. However, for the sequential model these probabilities do vary due to the 'super' region restrictions being unacceptable and therefore not imposed at the start up stage.

${ }^{x x i}$ These results of course beg the question why females were less interested in selfemployment.

${ }^{\text {xxii }}$ We are grateful to an anonymous referee for suggesting the latter two possibilities to us.

${ }^{x x i i i}$ Examples of the policies adopted by Scottish enterprise in an attempt to influence the culture and attitudes towards entrepreneurships included: press campaigns, a business game television series, several books on model Scottish entrepreneurs 'Local Heroes', a 'Year of the Entrepreneur' New Model Schools Enterprise programmes, University entrepreneurship centres, and the creation of an Entrepreneurial Exchange with significant private sector involvement allowing easy access to entrepreneurs, mentoring and information.

${ }^{\text {xxiv }}$ This can be attempted by developing both formal and informal networking structures, such as the private sector led Entrepreneurial Exchange in Scotland, and offering advice forums such as Personal Enterprise Shows. These were pioneered in Scotland by Scottish Enterprise and were part of the Personal Enterprise project, a 
national Road Show, marketed through a TV-led advertising campaign, with local exhibitions (the Personal Enterprise Show), and a follow-up programme delivered by Local Enterprise Companies. The Personal Enterprise Show is designed to offer inspiration and motivation on starting a business, including start-up Factbooks, access to entrepreneurs and advisers, and a self-assessment questionnaire (on PC) to help participants test their entrepreneurial capabilities. 